\title{
Formulation and evaluation of polyherbal hair oil
}

\author{
Amol A. Joshi, Pravin M. Dyawarkonda \\ Department of Pharmacognosy, Arvind Gavali College of Pharmacy, Satara, Maharashtra, India
}

\begin{abstract}
Aim: This study aimed at reviewing the importance of polyherbal hair oil for the treatment of common hair problems such as baldness, alopecia, hair fall, gray hair, dryness, and most common dandruff. Materials and Methods: The various herbal ingredients are used in the formulation are: Amla, Bhringraj, Yashtimadhu, Triphala, Henna, Neem, Aloe vera, hibiscus flowers, coconut oil, cow milk, grated coconut, and water. All ingredients provide essential nutrients such as vitamin, antioxidant, protein, terpenoids, and many essential oils to maintain normal function of sebaceous glands. Procedure for oil preparation is divided into two parts: (1) preparation of decoction of all the herbs and (2) oil preparation. Results and Discussion: Excellent results of hair growth were seen in formulation prepared by the abovementioned procedure. Formulated herbal oil was evaluated for various parameters such as specific gravity, viscosity, acid value, saponification value, $\mathrm{pH}$, and irritation tests. Conclusion: In general, herbal formulation provides good blend of vitamins, antioxidants, terpenoids, and essential oils. All the values in the evaluation of finished product showed that they are within the acceptable limits. Hence, it is concluded that the oil is beneficial in maintaining good growth of hairs, turning gray hairs to black, providing protection from dandruff, and results in lustrous hairs.
\end{abstract}

Key words: Tail, alopecia, baldness, phytonutrients

\section{INTRODUCTION}

$\mathrm{H}$ erbal cosmetics are prepared by the association of bioactive ingredients and pharmaceutical products. The presence of number of phytochemicals and botanicals in the herbal products have dual significance, one that they are used as cosmetics for body care and another that phytochemicals improve the biological functions of human body naturally results in healthy skin and hairs. ${ }^{[1]}$ As the name suggests, the herbal extracts means the extracts of herbs. It is an ancient methodology because its origin was discovered from the holy Vedas and in Unani scriptures. As the realization said that the chemical medicines are not always work as magic bullets and they may have side effects. The current trend moves toward the herbalism and use of natural products. Indian herbs are the richest source to be used in cosmetic industries. $^{[2]}$

Herbal cosmetics were gaining tremendous demand in the world market. There is a wide range of herbal cosmetic products used as beauty regime to satisfy the purpose of beautification. Adding herbs in cosmetics is safer for our skin. ${ }^{[3]}$ Herbal hair oils were serving the purpose of hair treatment. Herbal hair oil not only moisturizes scalp but also reverses dry scalp and dry hair conditions. It provides numerous essential nutrients required to maintain normal functions of the sebaceous gland and promote natural hair growth.

There are two categories of hair care products. They are hair tonics and hair grooming aids. Hair oil those contains herbal drugs are called as hair tonics. These are formulated by herbal extracts in an oil base. Hair oils are the hair care formulations applied for treatment of hair disorders such as baldness, greying of hairs, hair falling, and dryness of hairs.

\section{MATERIALS AND METHODS ${ }^{[4,5]}$}

All the required raw materials were procured from local market shop Wagdole Ayurvedics, Satara.

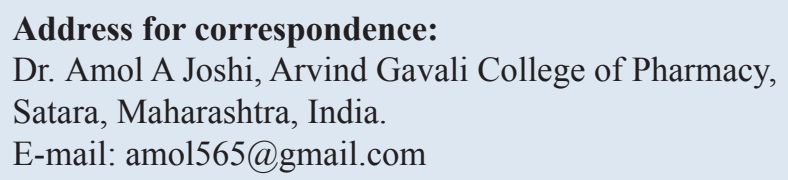

Received: $26-01-2017$

Revised: 08-02-2017

Accepted: 18-02-2017 


\section{Procedure for Preparation of Hair Oi[[6,7]}

The procedure involves 2 parts.

\section{Part 1-making decoction}

Kashayam (decoction) is the water extract of the herbs. Take all the herb powders - Amla, Bhringaraja, Liquoorice, Triphala, A. vera, Henna, Neem - into a wide-mouth vessel. While adding herbs, keep around $2 \mathrm{~g}$ of each of these herbs separately. Add the remaining part of the herbs to the vessel. Add water to it. Boil this mixture till you get around half quantity. While boiling, stir continuously. Boil on mild fire. Taking a wide-mouth big vessel helps avoid spilling of boiling Kashayam. After getting half quantity, filter the Kashayam.

\section{Part 2-oil preparation}

Take $200 \mathrm{ml}$ coconut oil in a big wide-mouth vessel. Add prepared Kashayam to it. Add $80 \mathrm{ml}$ milk to it. Put grated coconut into a mixer/grinder, add a little water, and grind it. Add the ground coconut along with liquid to the vessel. Add chopped hibiscus flower pieces into the vessel. Start heating the whole mixture on mild fire. Stir continuously. ${ }^{[9]}$

\section{Observations}

There is a need of complete removal of moisture from the oil. Hence, we got around $200 \mathrm{ml}$ of the oil. In the initial phase of boiling the oil, larger bubbles were observed. These bubbles indicate water being evaporated. In the initial phase, the whole mass looks very unclear. However, as the process moves on, the liquid becomes clearer. At the final stage, the vessel started exhibiting aroma, the powders turn into a paste, which you can roll into the form of a wick, and there will be formation of foam. After that, the big bubbles were disappeared. Then, we put the paste on spoon and heat it on mild fire; it does not produce any cracking sound. This indicates the complete removal of moisture from the oil. Stop heating at this precise point and filter it when it is hot.

\section{Evaluation Parameters ${ }^{[6,7]}$}

The formulated herbal hair oil was subjected to physical evaluation. ${ }^{[2]}$

\section{Specific Gravity}

Take the specific gravity bottle, rinse it with distilled water. Dry it in oven for $15 \mathrm{~min}$, cool, close it with cap and weigh it (a). Now, fill the same specific gravity bottle with the sample and close it with cap and again weigh it (b).

Determine the weight of sample per milliliter by subtracting the weight (b-a).

\section{Viscosity}

It is an index of resistance of a liquid to flow, the higher the viscosity of a liquid, the greater is the resistance to flow. The viscosity was determined by using Ostwald's viscometer.

$\mathrm{pH}$

The $\mathrm{pH}$ of herbal hair oil was determined using $\mathrm{pH}$ meter.

\section{Acid Value}

\section{Preparation of 0.1 molar solution}

Weigh $0.56 \mathrm{~g} \mathrm{KOH}$ pellets and dissolve in $100 \mathrm{ml}$ of distilled water and stir continuously. The prepared 0.1 molar $\mathrm{KOH}$ solution was filled in the burette.

\section{Preparation of sample}

Measure $10 \mathrm{ml}$ oil and dissolve in $25 \mathrm{ml}$ of ethanol and $25 \mathrm{ml}$ of ether mixture and shake. Add $1 \mathrm{ml}$ of phenolphthalein solution and titrate with 0.1 molar $\mathrm{KOH}$ solution.

Acid value $=5.61 \mathrm{~V} * \mathrm{~N} / \mathrm{W}$

Where, $\mathrm{V}=$ Volume of standard sodium hydroxide used $(\mathrm{ml})$, $\mathrm{N}=$ Normality of the sodium hydroxide solution, $\mathrm{W}=$ Weight of the sample (g).

\section{Saponification Value}

Accurately weigh $1 \mathrm{ml}$ of oil into a $250 \mathrm{ml}$ of conical flask and $10 \mathrm{ml}$ of ethanol:ether mixture (2:1) was added. To this flask, $25 \mathrm{ml}$ of $0.5 \mathrm{~N}$ alcoholic $\mathrm{KOH}$ was added. Keep the flask for $30 \mathrm{~min}$, and the flask was cooled. The cooled solution was titrated against $0.5 \mathrm{~N} \mathrm{HCl}$ using phenolphthalein as indicator. Similarly, the blank titration was performed without taking oil (sample). The amount of $\mathrm{KOH}$ in $\mathrm{mg}$ used was calculated.

Saponification value $=28.05^{*}(\mathrm{~B}-\mathrm{S}) / \mathrm{W}$

Where, $\mathrm{S}=\mathrm{ml}$ of $\mathrm{KOH}$ required to neutralize the substance, $\mathrm{B}=\mathrm{ml}$ of $\mathrm{KOH}$ required for blank, and $\mathrm{W}=$ Weight of the sample taken for the test $(\mathrm{g})$.

\section{RESULTS AND DISCUSSION}

Color and odor of the oil sample were typical of their constituents.

The $\mathrm{pH}$ of oil was found to be 6.8 which was relevant with human skin. 


\section{Common name, biological source, and family}

Coconut oil

C. nucifera, Arecaceae

Cow milk

Amla

E. officinalis, Euphorbiaceae

Bhringraj

E. alba, Asteraceae

Yashtimadhu

G. glabra, Leguminosae

Triphala

(Amla, Herda, Behda)

\section{Table 1: Plants used for preparation of herbal hair oil}

\section{Part used Uses}

Kernel

Raw material for hair oil and hair tonic, moisturizer

Milk

Hair nourishment, improves consistency.

Fruit

Antioxidant, treat the scalp ailments, hair growth

Whole

plant

Promoting hair growth, hair nourishment, antidandruff

Roots

Nourishes the scalp, heal damage, helps in hair growth

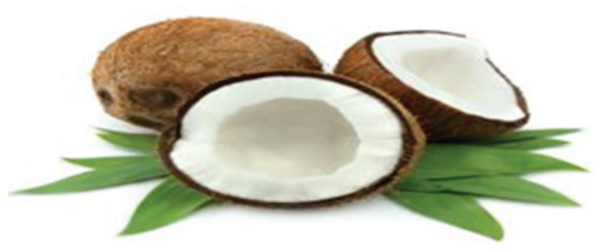

Figure
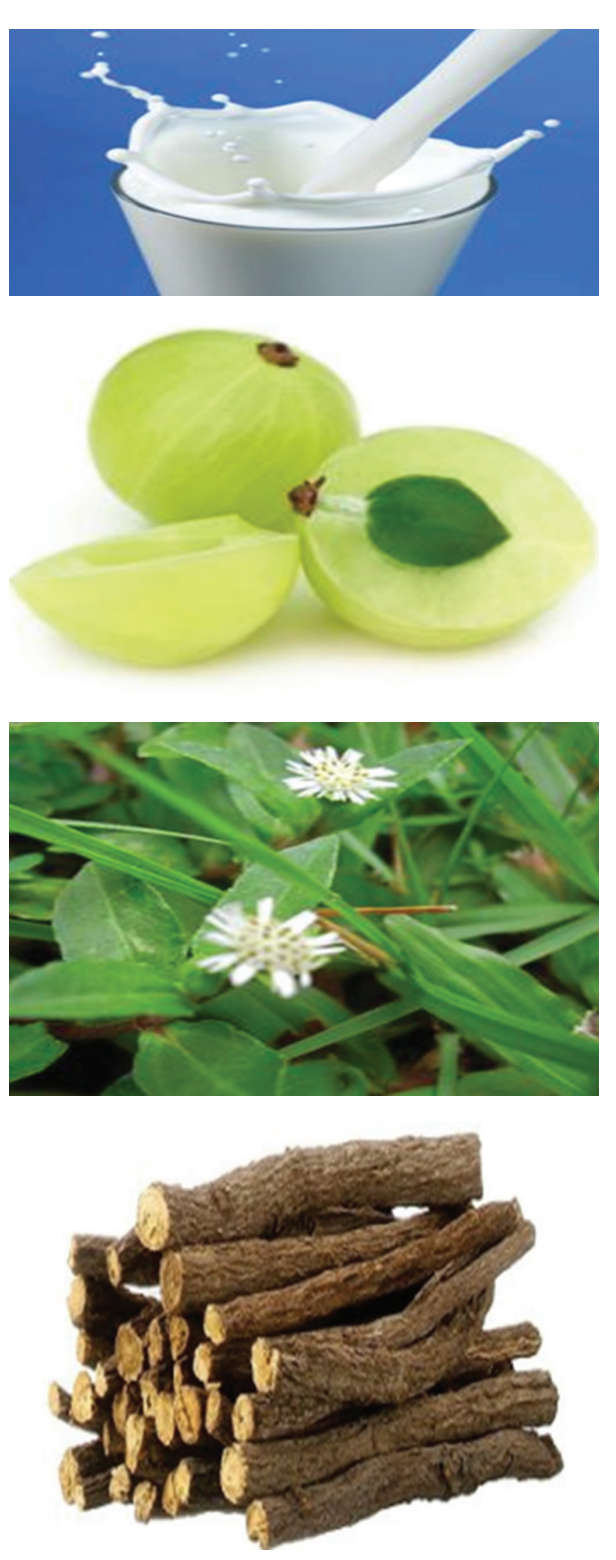

Fruits

Promoting hair growth

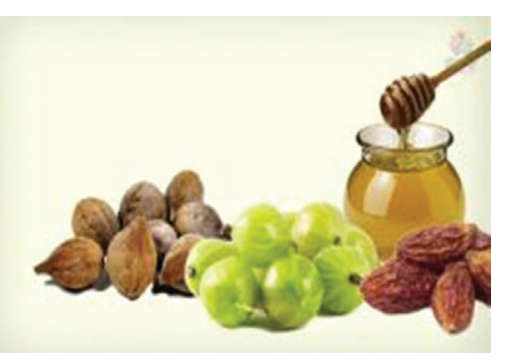

(Contd...) 


\begin{tabular}{|c|c|c|c|}
\hline & & able 1: (Continue & \\
\hline $\begin{array}{l}\text { Common name, biological } \\
\text { source, and family }\end{array}$ & Part used & Uses & Figure \\
\hline $\begin{array}{l}\text { Henna } \\
\text { L. inermis, Lythraceae }\end{array}$ & Leaves & As hair dye & \\
\hline $\begin{array}{l}\text { Neem } \\
\text { A. indica, Meliaceae }\end{array}$ & Leaves & $\begin{array}{l}\text { Antimicrobial, } \\
\text { antiseptic, } \\
\text { antidandruff }\end{array}$ & \\
\hline $\begin{array}{l}\text { A. vera } \\
\text { A. barbadensis, Liliaceae }\end{array}$ & Leaf pulp & $\begin{array}{l}\text { Moisturizer, } \\
\text { softening of hairs }\end{array}$ & \\
\hline $\begin{array}{l}\text { Hibiscus } \\
\text { H. rosa-sinensis, Malvaceae }\end{array}$ & $\begin{array}{l}\text { Flower } \\
\text { paste }\end{array}$ & $\begin{array}{l}\text { Provides nutrition } \\
\text { and hair shine }\end{array}$ & \\
\hline
\end{tabular}

C. nucifera: Coccus nucifera, E. officinalis: Emblica officinalis, E. alba: Eclipta alba, G. glabra: Glycyrrhiza glabra, L. inermis: Lawsonia inermis, A. indica: Azadirachta indica, A. barbadensis: Aloe barbadensis, H. rosa-sinensis: Hibiscus rosa-sinensis, A. vera: Aloe vera

The acid value is an indication of rancid state. More acid value indicates the higher percentage of free fatty acid. Lower the acid value, higher the yield/quantity of oil. The acid value of formulated hair oil was found to be 2.97 .

\section{CONCLUSION}

In general, the herbal formulation provides good blend of vitamins, antioxidants, terpenoids, and essential oils. All the 


\begin{tabular}{|c|c|}
\hline Ingredients & Quantity \\
\hline Coconut oil & $200 \mathrm{ml}$ \\
\hline Cow milk & $100 \mathrm{ml}$ \\
\hline Grated coconut water & $80 \mathrm{ml}$ \\
\hline Water & $400 \mathrm{ml}$ \\
\hline Amla (E. officinalis) & $20 \mathrm{~g}$ \\
\hline Bhringraj (E. alba) & $20 \mathrm{~g}$ \\
\hline Yashtimadhu (G. glabra) & $20 \mathrm{~g}$ \\
\hline Triphala & $20 \mathrm{~g}$ \\
\hline Henna (L. inermis) & $20 \mathrm{~g}$ \\
\hline Neem ( $A$. indica) & $20 \mathrm{~g}$ \\
\hline Aloe vera ( $A$. barbadensis) & $10 \mathrm{~g}$ \\
\hline Hibiscus flower ( $H$. rosa-sinensis) & $10 \mathrm{~g}$ \\
\hline \multicolumn{2}{|c|}{$\begin{array}{l}\text { E. officinalis: Emblica officinalis, E. alba: Eclipta alba, } \\
\text { G. glabra: Glycyrrhiza glabra, L. inermis Lawsonia inermis, } \\
\text { A. indica: Azadirachta indica, A. barbadensis: Aloe barbadensis, } \\
\text { H. rosa-sinensis: Hibiscus rosa-sinensis }\end{array}$} \\
\hline \multicolumn{2}{|c|}{ Table 3: Evaluation of herbal hair oil } \\
\hline Evaluation parameters & Results \\
\hline Specific gravity & 1.13 \\
\hline Viscosity & 0.026 centipoise \\
\hline Acid value & 2.97 \\
\hline Saponification value & 223.40 \\
\hline $\mathrm{pH}$ & 6.8 \\
\hline
\end{tabular}

values in the evaluation of finished product showed that they are within the acceptable limits. Hence, it is concluded that the oil is beneficial in maintaining good growth of hairs, turning grey hairs to black, providing protection from dandruff, and results in lustrous hairs.

\section{REFERENCES}

1. Saraf S. Herbal hair oil cosmetics: Advancements and recent findings. World J Pharm Res 2014;3:3278-94.

2. Dwivedi S. Formulation and evaluation of herbal hair oil. Int J Chem Sci 2012;10:349-53.

3. Mithal B, Shah R. A Hand Book of Cosmetics. $1^{\text {st }}$ ed. New Delhi: Vallabh Prakashan; 2000. p. 141-2.

4. Evans W. Pharmacognosy. $15^{\text {th }}$ ed. Edinburgh: Saunders Publishers Ltd.; 2002. p. 292.

5. Kapoor V. Herbal cosmetics for skin and hair care. Indian J Nat Prod Resour 2005;4:306-14.

6. Nema R. Preparation, evaluation and hair growth stimulating activity of herbal hair oil. J Chem Pharm Res 2009; $1: 261-7$.

7. Gautam S. Fomulation and evaluation of herbal hair oil. Int J Chem Sci 2012;10:349-53.

8. Kamal A. Physicochemical investigation of some herbal hair oil. Int J Pharm Sci Rev Res 2015;15:93-5.

Source of Support: Nil. Conflict of Interest: None declared. 